\title{
Influence of plaster drying on the amount of residual monomer in heat-cured acrylic resins
}

\author{
Tarcisio José de Arruda Paes-Junior', Rodrigo Furtado de Carvalho', Sâmia Carolina Mota Cavalcanti', \\ Guilherme de Siqueira Ferreira Anzaloni Saavedra', Alexandre Luiz Souto Borges ${ }^{1}$
}

'Department of Dental Materials and Prosthodontics, School of Dentistry, Institute of Science and Technology, UNESP - Univ Estadual Paulista, São José dos Campos, SP, Brazil

\begin{abstract}
Aim: To evaluate the influence of plaster condition, dry or not, on the amount of residual monomer in heat-cured acrylic resin. Methods: Thirty acrylic resin specimens $(65 \times 10 \times 3 \mathrm{~mm})$ were fabricated and randomly assigned to 5 groups $(n=6)$. The evaluated resins were heat-cured acrylic resins by conventional or microwave polymerization techniques and the plaster was previously dried in microwave oven in two groups. Each specimen was individually immersed in a test tube containing methanol (7 days) for surface analysis. In the groups for which internal monomer was evaluated, the specimens were fragmented and the small fragments were weighed prior to immersion in methanol. The analysis was made by high performance liquid chromatography (HPLC). Data were analyzed by ANOVA and Tukey test $(p<5 \%)$ Results: showed statistical differences among the groups. Conclusions: The previous plaster drying influenced the residual monomer amount showing a decrease of these levels.
\end{abstract}

Keywords: acrylic resins, polymers, chromatography, laboratory research.

\section{Introduction}

Several materials have been consolidated due to their broad use in several areas of dentistry ${ }^{1}$. Acrylic resin is one of the most typical examples, which since the 1940's has been established as the material of choice in the preparation of prosthetic works, such as complete and partial removable dentures ${ }^{2}$.

Advantages such as biocompatibility, no taste and odor, adequate thermal properties, dimensional stability, and simple technique are prevalent in these indications ${ }^{3-4}$. Although its extensive use has established defined criteria concerning its polymerization, especially in the case of hot water bath, some questions persist regarding the procedure for triggering the polymerization by microwave energy and the effects on the properties of the final product. Ilbay et al. ${ }^{5}(1994)$, focusing on the mechanism of action of microwave energy, described that it causes the

Received for publication: February 04, 2013 Accepted: March 21, 2013

Correspondence to: Tarcisio José de Arruda Paes-Junior Avenida José Longo, 777, São Dimas CEP: 12245-000 - São José dos Campos, SP, Brasil Phone: +551239479371 E-mail: tarcisio@fosjc.unesp.br vibration of water molecules in a substance two to three billion times per second and that it produces friction that results in the heating of substance. Those authors demonstrated that microwaves cause the molecules of the acrylic resin (monomer) to vibrate with higher frequency, creating friction and the heat that triggers the polymerization $^{5}$.

Studies on the heating of the monomer molecules that determine the formation of polymer chains by microwaves do not explain whether this process is incremented or not by heating the water contained in the plaster $^{3,5}$. De Clerck $^{6}$ (1987) found 
that when the monomer's boiling temperature $\left(100.8^{\circ} \mathrm{C}\right)$ is reached, there is formation of pores in the resin, which is more easily achieved when the heat generated by the resin cannot be released.

Verifying the factor related to the condition of plaster, studies have proposed to see how different types of plaster behave when submitted to drying in a microwave oven ${ }^{4,7-8}$. Luebke and $\mathrm{Chan}^{8}$ (1985) reported an increase in surface hardness in some of the tested dental plasters when microwave drying was performed. Berg et al. ${ }^{9}$ (2007) assessed the degree of disinfection of dental casts by means of microwave, and noticed that performing a cycle of $5 \mathrm{~min}$ at $900 \mathrm{~W}$ resulted in an effective disinfecting of these models without dimensional changes or macroscopic defects.

One of the points of major importance in the study of acrylic resins lies on analyzing the amount of monomer present in the polymerized material, which is not converted during the resin processing and can determine tissue damage, such as irritations or allergic reactions in oral tissues, and also cause undesirable changes in the mechanical properties of the material ${ }^{10}$. According to international standards, the content of monomer should not exceed $2.2 \%$ for heat-cured resin ${ }^{11}$. Urban et al. ${ }^{12}$ (2007) compared the effect of the amount of residual monomer when acrylic resin was subjected to post-polymerization by immersion in hot water bath and found similar reduced values of residual monomer for conventional or microwaving techniques.

It is questionable if the water contained in the plaster would influence in the resin process because in the conventional process the heat reaches the mass of resin indirectly, requiring first to heat the flask and the cast. Using microwave a dry plaster provides a more effective degree of polymerization. Then, the objective of this research was to determine whether previous plaster drying when polymerized by microwaves affects the superficial and internal amount of monomer.

\section{Material and methods}

\section{Preparation of specimens}

Two types of acrylic resins, one heat-cured in water bath (Lucitone 550; Dentsply Ind. Com Ltda, Petrópolis, RJ Brazil) and the other cured by microwave (VIPI-WAVE; Dental-Vipi Ltda., Pirassununga, SP, Brazil) were used in this study.

Rectangular stainless steel bars (12.6X67.0x3.0 mm) with sharp edges was included in fiberglass reinforced microwave flask (VIPI-STG; Dental-Vipi Ltda.), which was also used in the hot water bath in the conventional technique of acrylic resin polymerization. The process was initiated by embedding the base of the flask in freshly hand-mixed type II plaster (Plaster-Rio; Bussioli ME, Rio Claro, SP, Brazil) and then a condensation silicone (VIPI-SIL; Dental-Vipi Ltda.) was applied around the metallic bars and proceeded to fill the flask with a new quantity of plaster.

Five groups (Table 1) were formed according to type of acrylic resin, plaster drying and polymerization and, after $1 \mathrm{~h}$, the metallic bars were removed and the acrylic resin was prepared according to the manufacturer's recommendations
Table 1- Groups set based on the type of resin, plaster and condition of polymerization cycle

\begin{tabular}{llcc}
\hline Group & Acrylic Resin & Plaster drying & Polymerization \\
1A & Lucitone 550 & No & Microwave \\
2A & Vipi-Wave & No & Microwave \\
1B & Lucitone 550 & Yes & Microwave \\
2B & Vipi-Wave & Yes & Microwave \\
3 & Lucitone 550 & No & Water Bath \\
\hline
\end{tabular}

and placed in the flask when reached the plastic phase. After that, the flask was kept closed for 30 min under pressure, for all groups.

For the control group the polymerization process was undertaken using a long cycle in water bath when the flasks were positioned in cool water, then taken to $72^{\circ} \mathrm{C}$ for $9 \mathrm{~h}$ and next the temperature was increased to $100^{\circ} \mathrm{C}$ for 1 hour.

Groups 1A, 2A, 1B, 2B, in which the proposal was the previous drying of plaster, the methodology described by Hersek et al. ${ }^{13}$ (2002) was used proceeding the drying in a microwave oven for $10 \mathrm{~min}$ at $600 \mathrm{~W}$, where parts of the flask were kept separate during the cycle.

After this cycle, flasks were left at room temperature for $1 \mathrm{~h}$ until complete cooling was reached. The flask parts were kept open and were stored in an oven at $37^{\circ} \mathrm{C}$ for 2 hours for drying and then the polymerization method was established.

For the microwave polymerization a Continental AW30 microwave oven (BS Continental Amazonia Ind. e Com., Manaus, AM, Brazil) was used with a turntable plate, frequency of $2450 \mathrm{MHz}$ and maximum power of $900 \mathrm{~W}$, and the cycle was to maintain $20 \%$ of the device power for 20 min, followed by an additional cycle at $60 \%$ of the power for another $5 \mathrm{~min}$.

Completing the polymerization cycles proposed for each group, the flask was kept for about $2 \mathrm{~h}$ at room temperature until complete cooling.

\section{Analysis of residual monomer}

For the analysis of the surface residual monomer, glass test tubes with lids were filled with $20 \mathrm{~mL}$ of methyl alcohol PA - methanol. One specimen was immersed in each of the tubes and was kept in this condition at approximately $2^{\circ} \mathrm{C}$ for 7 days. After this period, the specimens were removed from test tubes and the residual monomer in the solvent was quantified.

High Performance Liquid Chromatography (HPLC) was used with a chromatographer LS 10 AD (Dionex Corporation, Sunnyvale, CA, USA), column RP-18 $250 \mathrm{~mm}$ long by 2.5 $\mathrm{mm}$ diameter, attached to a detector UV-VIS (Dionex Corporation), at a wavelength of $225 \mathrm{~nm}$. Calibration curve for the pure monomer (liquid) was determined from each of the tested resins. Regarding the analysis of groups, just as for the preparation of the calibration curve, from each test tube it was withdrawn an aliquot of $20 \mu \mathrm{L}$. The area was identified numerically and for each monomer concentration three samples were injected and the average value of these areas was calculated.

With the average value of the areas for all checked 


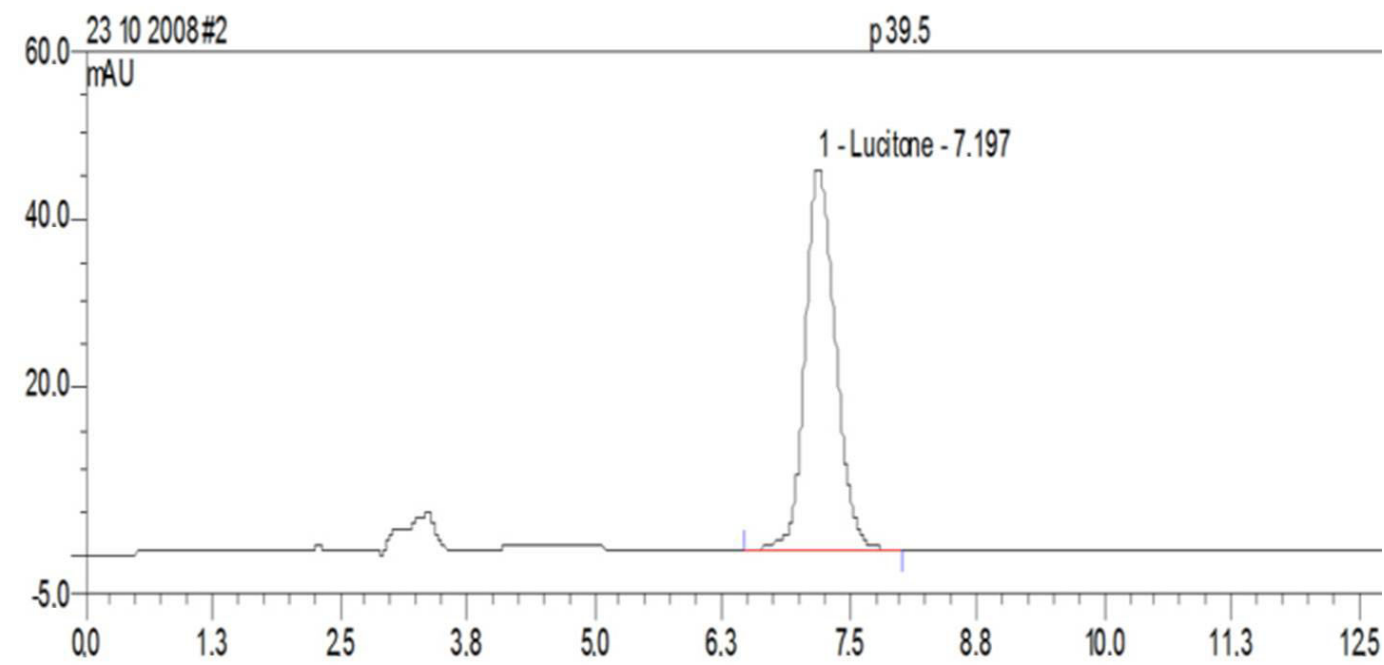

Fig. 1. Chromatogram for the sample of Vipi-Wave of methyl methacrylate for both groups.

dilutions (Chromeleon version 6.70 (Chromeleon Inc., Sunnyvale, CA, USA) program did the mathematical calculation and rendered the area number for the unit of measurement in $\mu \mathrm{g} / \mathrm{mL}$. Calculation of values for each sample was divided by this constant measure of surface area, which allowed obtaining results in $\mu \mathrm{g} / \mathrm{cm}^{2}$ (Figure 1).

For the analysis of the internal monomer the polymerized material was reduced to small particles, to enable greater contact of the substance and solvent (methanol). Specimens previously weighed as described above $(n=3)$ were targeted without warming the material during this process. The mass of the particulate material was recorded on a digital precision scale and the results varied from $0.540 \mathrm{mg}$ to $0.650 \mathrm{mg}$. This was put into test tubes with lids, containing methanol, similar to that described for the analysis of residual monomer surface. After 7 days the particulate material was removed from the solvent and the monomer quantified.

The figures were compiled, distributed and assessed comparatively by one-way ANOVA and Tukey's test at 5\% significance level (Statistic for Windows program, StatSoft South America, São Caetano do Sul, SP, Brazil).

\section{Results}

There were statistically significant differences among groups $(\mathrm{p}<0.05)$, with group 3 (control) showing the lowest levels of residual surface monomer (Table 2), but no significant was found among the other groups.

Among the studied groups, one that showed higher values of surface monomer was group 2A (Vipi-Wave) in the microwave cycle set by the manufacturer. The chart in Figure 2 illustrates average values for the surface monomer.

The results for the internal monomer showed statistically significant difference $(\mathrm{p}<0.05)$ only between group $2 \mathrm{~A}$ and the other groups, with $2 \mathrm{~A}$ showing the highest values.

The values and averages of groups, including Tukey test results, are shown in Tables 3 and 4 and Figure 3.

Total values in ìg of the percentages in each internal monomer of all groups are shown in Table 5.

\section{Discussion}

Several studies have been focusing on this analysis by considering the influence of aspects such as methods and polymerization cycles and also storage time of the polymerized material ${ }^{14-15}$. Another point discussed in literature involves tissue behavior in excessive amounts of free monomer and in the oral environment, which explain irritation of smaller proportions and the existence of severe hypersensitivity reactions to this product $^{16}$.

Based on the idea of De Clerck $^{6}$ (1987) who claimed that it is relevant for effective polymerization that during a microwave polymerization cycle the plaster contained in the flask is rather dry, it was considered important to analyze the possible effects of it in the final outcome of work, focusing on assessing the amount of residual monomer.

It is known that the microwave enables the vibration of molecules of liquids, mainly water ${ }^{17}$. According to Nishii ${ }^{18}$ (1968), the monomer molecules present in the mass of the resin are agitated by the electromagnetic wave generated by

Table 2- Means, standard deviations and Tukey's test results for superficial residual monomer numbers in $\mu \mathrm{g} / \mathrm{cm}^{2}$ for the analyzed groups

\begin{tabular}{lcccc}
\hline Groups $^{*}\left(\mu \mathrm{g} / \mathrm{cm}^{2}\right)$ & & & & \\
$1 \mathrm{~A}$ & $2 \mathrm{~A}$ & $1 \mathrm{~B}$ & $2 \mathrm{~B}$ & 3 \\
$11.91 \pm 0.89 \mathrm{~b}$ & $39.54 \pm 7.18 \mathrm{c}$ & $7.75 \pm 0.83 \mathrm{ab}$ & $10.46 \pm 3.16 \mathrm{ab}$ & $3.46 \pm 0.51 \mathrm{a}$ \\
\hline
\end{tabular}

Different lowercase letters in the row reveal differences among the means. 


\section{Superficial Monomer}

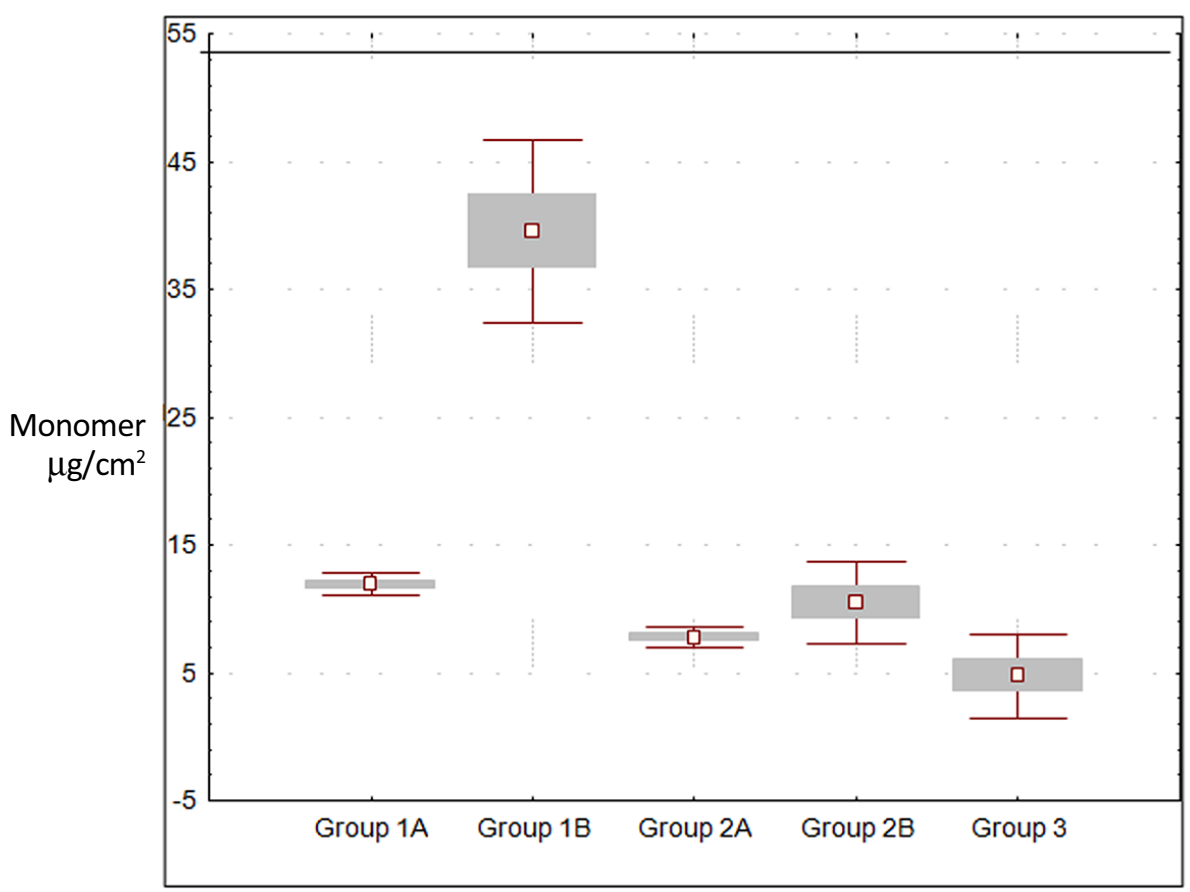

Acrylic Resin

Fig. 2. Means and standard deviations for the amount of surface residual monomer in $\mu \mathrm{g} / \mathrm{cm}^{2}$.

\section{Superficial Monomer}

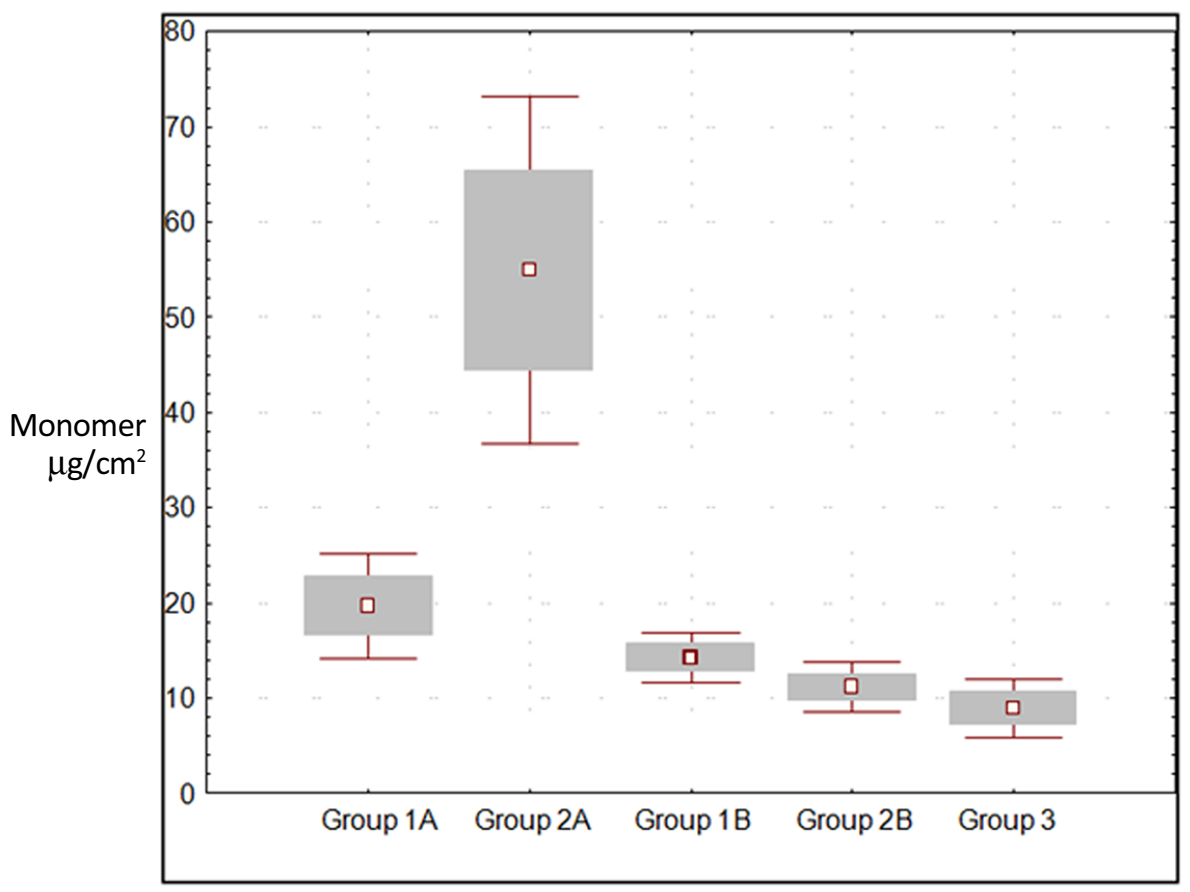

\section{Acrylic Resin}

Fig. 3. Means and standard deviations for the amount of internal residual monomer in $\mu \mathrm{g} / \mathrm{ml}$.

the device, and the friction of these molecules would promote the release of heat required to trigger the conversion of monomer and forming polymer, hence, new polymer chains ${ }^{5-6}$.
There was a decrease in the quantity of surface monomer, when the plaster was dried prior to resin pressing. Both resins, one formulated for microwave use and the other for 
Table 3- Means and standard deviations (S.D.) for the amounts of internal residual monomer in $\mu \mathrm{g} / \mathrm{ml}$

\begin{tabular}{llllll}
\hline $\begin{array}{l}\text { Sample } \\
\boldsymbol{\mu g} / \mathrm{ml}\end{array}$ & Groups & & & & \\
& 1A & 2A & 1B & 2B & 3 \\
I & 14.52 & 71.75 & 17.00 & 8.86 & 7.67 \\
$\|$ & 25.44 & 57.60 & 13.90 & 13.92 & 6.77 \\
III & 19.03 & 35.46 & 11.83 & 10.79 & 12.46 \\
Means & 19.66 & 54.93 & 14.24 & 11.19 & 8.96 \\
SD & 5.48 & 18.29 & 2.60 & 2.55 & 3.05 \\
\hline
\end{tabular}

Table 4- Results of Tukey test for the values of surface residual monomer $\mu \mathrm{g} / \mathrm{cm}^{2}$ for the analyzed groups

\begin{tabular}{lllll}
\hline 1 A & 2A & 1B & 2B & 3 \\
$19.66 \mathrm{a}$ & $54.93 \mathrm{~b}$ & $14.24 \mathrm{a}$ & $11.19 \mathrm{a}$ & $8.96 \mathrm{a}$ \\
\hline
\end{tabular}

* Different lowercase letters in the rows reveal differences among the averages.

Table 5- Total values in $\mu \mathrm{g}$ of the percentages in each internal monomer samples

\begin{tabular}{llllll}
\hline Samples & Groups & & & \\
total mass $(\mathrm{mg})$ & 1A & 2A & 1B & 2B & 3 \\
\cline { 2 - 6 }$I(\%)$ & 630 & 540 & 607 & 629 & 627 \\
total mass $(\mathrm{mg})$ & 0.04 & 0.26 & 0.05 & 0.02 & 0.02 \\
II(\%) & 613 & 603 & 643 & 649 & 631 \\
total mass $(\mathrm{mg})$ & 0.08 & 0.18 & 0.04 & 0.04 & 0.01 \\
III(\%) & 640 & 563 & 644 & 655 & 647 \\
\hline
\end{tabular}

conventional water bath, were used in the microwave oven. In this sense, it may be hypothesized that for microwave processing the amount of water plaster does not aid in the polymerization process. On the contrary, it interferes partially with the polymerization, probably "absorbing" a part of the electromagnetic energy, which act on the molecules of the monomer, confirming the indicative data of De Clerck ${ }^{6}$ (1987).

The importance of quantifying the monomer by HPLC chromatography lies in the possibility of accurately verifying differences in these quantities, even though, from the clinical point of view, for the type of used materials, the values obtained are within acceptable standards for use of acrylic resin. Several authors used this approach and found similar results ${ }^{19}$.

Other aspects are relevant in this analysis, which proved the possibility of microwave polymerization of a conventional heatcured resin, presenting similar monomer values to those found for the resin formulated for microwave when the plaster was dry. These data corroborate with the studies of Lombardo et $a .^{20}(2012)$ which confirmed the possibility of polymerizing in microwave a conventional heat-cured resin, such as Lucitone 550.

For the analysis of internal monomer, the variation of individual values of the samples was higher than the quantification of the surface monomer. This may possibly be explained by the larger number of different segments of the resin which were immersed in methanol and resulting in a greater heterogeneity of surface areas in contact with the solvent.
The control group had lower levels of residual monomer than the groups polymerized by microwave. Other works presented a similarity of concentrations for water bath cycles and microwave; although when considering the time factor, the microwave cycle proposed by the manufacturer of Vipi Wave resin and applied to the other groups, it was a total of $25 \mathrm{~min}$ and did not present greater values of residual monomer than the control group, which used the long cycle in warm water for a total of $13 \mathrm{~h}$. These data agree with the results obtained by Urban et al. ${ }^{12}(2007)$, Jorge et al. ${ }^{21}$ (2003), Zissis et al. ${ }^{22}$ (2008), who found low levels of residual monomer for heat-cured resins regardless of the polymerization method.

Another important and justified concern is about the relationship between the setting time and power for better polymerization. Same researchers agree on the fact that starting a microwave cycle with lower power and longer time and ending it with increased power and decreased time, the polymerization becomes more effective ${ }^{17}$.

Data obtained in this study showed variations that may be an indication of possible changes in the characteristics of the material when considering increases in the thickness of acrylic resin, because it is known that there is a correlation between degree of polymerization and amount of free monomer on the mechanical properties, such as hardness, transverse resistance and roughness ${ }^{17}$. Therefore, other studies are required involving plaster drying, in order to verify whether there is variation in the behavior of the resin when considering other properties, such as flexural strength, porosity, dimensional stability, toughness and other mechanical characteristics.

It is possible to conclude that: plaster drying prior to the resin polymerization resulted in a decreased amount of monomer, regardless of acrylic resin brand tested; regarding the amount of internal residual monomer, plaster drying caused a significant decrease of these values for the groups of Vipi-Wave resin; the conventional polymerization of acrylic resin in hot water bath (control group) determined the lowest levels of surface residual monomer; the polymerization of the resin Lucitone in microwave was feasible, presenting low levels of surface and internal residual monomer, a fact that corroborates the use of microwave cycle for this resin as a reliable alternative to polymerization.

\section{Acknowledgments}

- Foundation for Development of UNESP-FUNDUNESP for financial support.

- Vera Lucia Tedeschi Savoy, DDS - São Paulo Biological Institute

\section{References}

1. Baydas S, Bayindir F, Akyil MS. Effect of processing variables (different compression packing processes and investment material types) and time on the dimensional accuracy of polymethyl methacrylate denture bases. Dent Mater J. 2003; 22: 206-13. 
2. Kalsi HJ, Wang YJ, Bavisha K, Bartlett D. An audit to assess the quality and efficiency of complete and partial dentures delivered by junior hospital staff. Eur J Prosthodont Restor Dent. 2010; 18: 8-12.

3. Yannikakis S, Polychronakis N, Zissis A. Temperature rise during intraoral polymerization of self-cured hard denture base liners. Eur J Prosthodont Restor Dent. 2010; 18: 84-8.

4. Lopes MC, Consani RL, Mesquita MF, Sinhoreti MA, Consani S. Effect of monomer content in the monomer-polymer ratio on complete denture teeth displacement. Braz Dent J. 2011; 22: 238-44.

5. Ilbay SG, Guvener S, Alkumru HN. Processing dentures using a microwave technique. J Oral Rehabil. 1994; 21: 103-9.

6. De Clerck JP. Microwave polymerization of acrylic resins used in dental prostheses. J Prosthet Dent. 1987; 57:650-8.

7. Ghani F, Kikuchi M, Lynch CD, Watanabe M. Effect of some curing methods on acrylic maxillary denture base fit. Eur J Prosthodont Restor Dent. 2010; 18: 132-8.

8. Luebke RJ, Chan KC. Effect of microwave oven drying on surface hardness of dental gypsum products. J Prosthet Dent. 1985; 54: 431-5.

9. Berg E, Nielsen O, Skaug N. Efficacy of high-level microwave disinfection of dental gypsum casts: the effects of number and weight of casts. Int $\mathrm{J}$ Prosthodont. 2007; 20: 463-4.

10. Melilli D, Currò G, Perna AM, Cassaro A. Cytotoxicity of four types of resins used for removable denture bases: in vitro comparative analysis. Minerva Stomatol. 2009; 58: 425-34.

11. Yilmaz H, Aydin C, Caglar A, Yasar A. The effect of glass fiber reinforcement on the residual monomer content of two denture base resins. Quintessence Int. 2003; 34: 148-53.

12. Urban VM, Machado AL, Oliveira RV, Vergani CE, Pavarina AC, Cass QB. Residual monomer of reline acrylic resins. Effect of water-bath and microwave post-polymerization treatments. Dent Mater. 2007; 23: 363-8.

13. Hersek N, Canay S, Akça K, Ciftçi Y. Tensile strength of type IV dental stones dried in a microwave oven. J Prosthet Dent. 2002; 87: 499-502.

14. Consani RL, Monteiro VL, Mesquita MF, Consani S. The influence of storage on dimensional changes in maxillary acrylic denture bases and the effect on tooth displacement. Eur J Prosthodont Restor Dent. 2011; 19: 105-10.

15. Rizzatti-Barbosa CM, Ribeiro-Dasilva MC. Influence of double flask investing and microwave heating on the superficial porosity, surface roughness, and Knoop hardness of acrylic resin. J Prosthodont. 2009; 18: 503-6.

16. de Andrade Lima Chaves C, Machado AL, Vergani CE, de Souza RF, Giampaolo ET. Cytotoxicity of denture base and hard chairside reline materials: a systematic review. J Prosthet Dent. 2012; 107: 114-27.

17. Lai CP, Tsai MH, Chen M, Chang HS, Tay HH. Morphology and properties of denture acrylic resins cured by microwave energy and conventional water bath. Dent Mater. 2004; 20: 133-41.

18. Nishii M. Curing of denture base resins with microwave irradiation: with particular reference to heat-curing resins. J Osaka Dent Univ. 1968; 2: 23-40.

19. Urban VM, Machado AL, Vergani CE, Giampaolo ET, Pavarina AC, de Almeida FG, et al. Effect of water-bath post-polymerization on the mechanical properties, degree of conversion, and leaching of residual compounds of hard chairside reline resins. Dent Mater. 2009; 25: 662-71.

20. Lombardo CE, Canevarolo SV, Reis JM, Machado AL, Pavarina AC, Giampaolo ET, et al. Effect of microwave irradiation and water storage on the viscoelastic properties of denture base and reline acrylic resins. J Mech Behav Biomed Mater. 2012; 5: 53-61.

21. Jorge JH, Giampaolo ET, Machado AL, Vergani CE. Cytotoxicity of denture base acrylic resins: a literature review. J Prosthet Dent. 2003; 90 : 190-3.

22. Zissis A, Yannikakis S, Polyzois G, Harrison A. A long term study on residual monomer release from denture materials. Eur $\mathrm{J}$ Prosthodont Restor Dent. 2008; 16: 81-4 